pronounced inverse association with birth weight without adjustment for other birth dimensions, and adjustments for both birth length and head circumference strengthened the association with haemorrhagic stroke. These data do not support a special role for birth weight relative to head size, but they suggest that the risk of haemorrhagic stroke is related to impaired growth of soft tissue mass relative to bone growth. ${ }^{4}$

The established aetiology of stroke differs by subtype, although hypertension is an important risk factor for occlusive and haemorrhagic stroke. Raised blood pressure is also associated with impaired fetal growth. ${ }^{5}$ However, whether the difference between stroke subtypes in the strength of the association of stroke with birth weight is mediated by blood pressure has yet to be established.

We thank Rawya Mohsen for managing the study database.

Contributors: EH and DL wrote the paper. EH carried out the analyses. MGK acted as the statistical expert in the study, and
HL contributed with his knowledge of the cohort and stroke. DL had the original study idea and will act as the guarantor of the paper.

Funding: The Uppsala birth cohort study was established using grants from the UK Medical Research Council and the Swedish Council for Social Research. No funding was received towards the study.

Competing interests: None declared.

1 Leon DA, Lithell HO, Vågerö D, Koupilová I, Mohsen R, Berglund L, et al. Reduced fetal growth rate and increased risk of death from ischaemic heart disease: cohort study of 15000 Swedish men and women born 1915-29. BMJ 1998;317:241-5

2 National Board of Health and Welfare, Sweden. Hospital discharge register. http://www.sos.se/epc/par/pareng.htm (accessed 20 July 2001).

3 Eriksson JG, Forsen T, Tuomilehto J, Osmond C, Barker DJ. Early growth, adult income, and risk of stroke. Stroke 2000;31:869-74.

4 Leon DA, Johansson M, Rasmussen F. Gestational age and growth rate of foetal mass are inversely associated with systolic blood pressure in young adults: an epidemiologic study of 165,136 Swedish 18-year old men. AmJ Epidemiol 2000;152:597-604.

5 Huxley RR, Shiell AW, Law CM. The role of size at birth and postnatal catch-up growth in determining systolic blood pressure: a systematic review of the literature. J Hypertens 2000;18:815-31.

(Accepted 10July 2001)

\title{
Unnecessary school absence after minor injury: case-control study
}

Peter M Barnes, Lorna Price, Alison Maddocks, Ronan A Lyons, Pam Nash, Michael McCabe

Department of Community Child Health, Swansea NHS Trust, Central Clinic, Swansea SA1 1LT

Peter M Barnes specialist registrar Lorna Price staff grade doctor Alison Maddocks consultant

Department of Public Health, Iechyd Morgannwg Health Authority, Swansea SA1 1LT Ronan A Lyons senior lecturer

Local Accident Centre, Neath

General Hospital,

Neath SA11 2LQ

Pam Nash

consultant

Accident and

Emergency

Department,

Swansea NHS

Trust, Morriston

Hospital, Swansea

SA6 6NL

Michael McCabe

consultant

Correspondence to:

A Maddocks

alison.maddocks@

swansea-tr.wales.

nhs.uk

BMJ 2001;323:1034-5
Children acquire many of the academic and social skills they need for their adult lives at school. Excessive absence from school is associated with educational failure, particularly when children miss more than $11 \%$ of school days. ${ }^{1}$ Each year, one in three British children goes to an emergency department for treatment, predominantly with minor injuries, but the effect on school attendances has not been quantified. ${ }^{2}$

This study was designed to investigate the number of days missed from school after children attended one of three local emergency departments with minor injuries. We defined minor injuries as those not requiring admission to hospital and not affecting mobility or the ability of the child to care for himself or herself.

\section{Method and results}

This case-control study involved children resident in, and attending school full time in, the Welsh counties of Swansea and Neath Port Talbot during the autumn school term of 1999. A case was defined as a child who attended the local emergency department on a Sunday preceding a school week with an injury that should not prevent school attendance. The children and their families were not informed of inclusion in the study. The next child of the same sex on the class register was chosen as a matched control. Ethical approval was obtained from Morgannwg Local Research Ethics Committee.

For each case, we obtained the age, sex, home postcode, school attended, and nature of the injury from the emergency department's records. School attendance for each half day in the week that followed the injury was recorded from the school register for the case pupil and the matched control (along with the
Relation between minor injuries and subsequent school attendance in pupils in full time education in two Welsh counties

\begin{tabular}{lcc} 
Injury & $\begin{array}{c}\text { Number (\%) of } \\
\text { injuries }\end{array}$ & $\begin{array}{c}\text { Mean (range) number of } \\
\text { half days }\end{array}$ \\
\hline Bruise & $115(27)$ & $7.9(0-10)$ \\
\hline Sprain & $110(26)$ & $7.1(0-10)$ \\
\hline Laceration & $66(16)$ & $6.7(0-10)$ \\
\hline Fracture & $57(14)$ & $5.5(0-10)$ \\
\hline Head injury & $28(7)$ & $7.8(0-10)$ \\
\hline Puncture wound & $9(2)$ & $7.3(0-10)$ \\
\hline Bite & $8(2)$ & $6.9(0-10)$ \\
\hline Abrasion & $7(2)$ & $8.0(2-10)$ \\
\hline Nasal injury & $7(2)$ & $6.9(1-10)$ \\
\hline Eye injury & $6(1)$ & $8.7(4-10)$ \\
\hline Burn/scald & $5(1)$ & $6.0(0-10)$ \\
\hline Foreign body & $3(1)$ & $9.3(8-10)$ \\
\hline Haemarthrosis & $1(<1)$ & 0 \\
\hline All & 422 & $7.4(0-10)$ \\
\hline
\end{tabular}

${ }^{\star}$ Tissue injury such as from a splinter or metal fragment.

control pupil's home postcode). For a randomly chosen sample of 100 pairs, we recorded the school attendance for each half day in the school week that preceded the minor injury.

Differences in school attendance between the matched pairs were analysed by using the one sample $t$ test and Wilcoxon's matched pairs signed ranking test. A Townsend small area deprivation score was calculated for each child, and the children's attendances were analysed in relation to these scores. ${ }^{3}$

Overall, 422 case-control pairs were identified in 130 schools; 251 (59\%) pairs comprised boys. Ages ranged from 4 to 16 years (mean 10.6 years). The type and frequency of injury were recorded along with the mean number of half days present in school for each injury type (table). 
We excluded 57 minor fractures and one haemarthrosis from further analysis as they could be argued to be more serious injuries. We analysed attendance for the remaining 364 case-control pairs only.

Case children attended significantly fewer half days in school after injury than control children (7.38 v 9.40, $\mathrm{P}<0.001)$. Deprivation scores for matched pairs did not differ significantly, and there was no association between missed time at school and deprivation score. Mean half day attendance in the week preceding injury did not differ significantly between case children and control children $(9.25 v 9.59, \mathrm{P}>0.1)$.

\section{Comment}

On average, one full school day was missed unnecessarily after children presented to hospital emergency departments with minor injuries. As children with and without injuries had similar previous school attendance, the resulting loss could be attributed to the injury. The cumulative loss was great given the high frequency of such injuries. Repeated absences of this type could contribute to educational difficulties, especially in children whose attendance is already suboptimal for other reasons.

We propose that health professionals are more proactive in stressing the importance of children attending school after minor injury when there is no medical reason to prevent attendance. Improved liaison between emergency departments, school health services, and local education authorities might help to reduce the unnecessary burden of minor injury.

We are grateful for the valuable assistance of the emergency department staff, all participating schools, and Mrs Lisa Webb for her secretarial help.

Contributors: MM had the original idea for the study and, together with PN, facilitated the collection of data in the accident and emergency departments and drew up definitions for minor injury. AM facilitated the interagency and interdepartmental working, liaised with the education authority, submitted the application to the ethics committee, and is guarantor for the study. PB and LP designed the data collection form, collected the data, established the database, liased with individual schools, and input the data. RL advised on the research method, provided statistical advice, and analysed the data. The paper was written jointly by all authors.

Funding: None.

Competing interests: None declared.

1 Klerman LV. School absence-a health perspective. Pediatr Clin North Am 1988;35:1253-69.

2 Lyons RA, Lo SV, Heaven M, Littlepage BNC. Injury surveillance in children-usefulness of a centralised database of accident and emergency attendances. Inj Prev 1995;1:173-6.

3 Townsend P, Phillimore P, Beattie A. Health and deprivation: inequality and the north. London: Croom Helm, 1998.

(Accepted 11 July 2001)

\title{
Social deprivation in Duchenne muscular dystrophy: population based study
}

\author{
Kate Bushby, Simon Raybould, Sara O'Donnell, James G Steele
}

Duchenne muscular dystrophy is an X linked disorder affecting approximately 1 in 3500 male live births. The incidence remains stable in most populations, maintained by a high rate of new mutations in the dystrophin gene. ${ }^{1}$ We observed that a higher than expected proportion of families of patients with Duchdeprived background, even at the time of first diagnosis (usually by age 5). We measured the level of material deprivation based on the place of residence at the time of diagnosis of all patients with Duchenne muscular dystrophy in the north of England to test the hypothesis that this single gene disorder is associated with social deprivation. enne muscular dystrophy seemed to be from a

\section{Participants, methods, and results}

Records of children with Duchenne muscular dystrophy in the Northern region of England have been scrupulously maintained since the 1960s, and we believe that ascertainment in the region is complete. We analysed data from the whole group of families with Duchenne muscular dystrophy in the region and also subdivided the group into four categories according to the origin of the mutation in the family (table).

In all, 229 of the 246 families with children diagnosed as having Duchenne muscular dystrophy between 1967 and 1999 in the Northern region had valid postcodes available at diagnosis. We linked

Townsend scores of enumeration districts with and without families with Duchenne muscular dystrophy

\begin{tabular}{|c|c|c|c|c|c|c|c|}
\hline \multirow[b]{2}{*}{ Group } & \multicolumn{4}{|c|}{ Duchenne muscular dystrophy } & \multicolumn{2}{|c|}{$\begin{array}{l}\text { No Duchenne muscular } \\
\text { dystrophy ( } n=6624)\end{array}$} & \multirow[b]{2}{*}{ Significance } \\
\hline & No & Median & Range & $\begin{array}{l}\text { Interquartile } \\
\text { range }\end{array}$ & Median & $\begin{array}{l}\text { Interquartile } \\
\text { range }\end{array}$ & \\
\hline All cases & 229 & 3.44 & -5.74 to 10.12 & 0.34 to 5.45 & 1.46 & -2.04 to 4.74 & $P<0.0001$ \\
\hline History in earlier generation & 42 & 3.15 & -5.74 to 10.12 & 0.65 to 5.05 & 1.46 & -2.04 to 4.74 & $P<0.0001$ \\
\hline New mutation in mother & 62 & 4.45 & -4.71 to 9.59 & 1.76 to 5.63 & 1.46 & -2.04 to 4.74 & $P<0.0001$ \\
\hline New mutation in child & 40 & 2.63 & -5.66 to 8.46 & -0.38 to 4.96 & 1.46 & -2.04 to 4.74 & $P=0.001$ \\
\hline No earlier history: mutation origin unknown & 85 & 3.35 & -2.63 to 7.41 & -1.87 to 5.36 & 1.46 & -2.04 to 4.74 & $\mathrm{P}<0.0001$ \\
\hline
\end{tabular}

Institute of Human
Genetics,
International
Centre for Life,
Newcastle upon
Tyne NE1 3BZ
Kate Bushby
professor of
neuromuscular
genetics methods are on the BMJ's website 